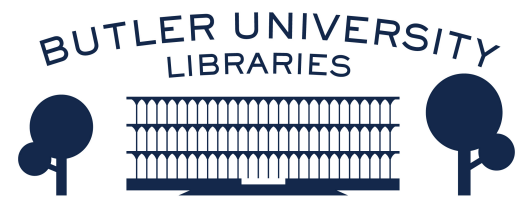

Journal of Hindu-Christian Studies

Volume 6

Article 12

January 1993

\title{
Viewpoints: Environmental Awareness: The Hindu Perspective
}

R. Vijayalakshmi

Follow this and additional works at: https://digitalcommons.butler.edu/jhcs

Part of the Religion Commons

\section{Recommended Citation}

Vijayalakshmi, R. (1993) "Viewpoints: Environmental Awareness: The Hindu Perspective," Journal of Hindu-Christian Studies: Vol. 6, Article 12.

Available at: https://doi.org/10.7825/2164-6279.1081

The Journal of Hindu-Christian Studies is a publication of the Society for Hindu-Christian Studies. The digital version is made available by Digital Commons @ Butler University. For questions about the Journal or the Society, please contact cbauman@butler.edu. For more information about Digital Commons @ Butler University, please contact digitalscholarship@butler.edu. 
some of the values underlying the environmental concern for a clean, safe and green Earth coincide with the basic Christian values in confronting the moral problem of social relationships and respect and responsibility for 'all of God's creation.

\section{Notes}

1 Mary, the Queen of all creation, according to the Byzantine theologians, is the fertile virginal Mother Earth that receives from the Spirit, not only at the Annunciation, but as a continued state of total surrender to God, the impregnation of God's word. The Blessed Mother by readily saying 'yes' to God, became a new woman to begin again a new creation. Her 'Fiat' was the total expression of her 'Faith'.

2 The Narmada dam project is a World Bank sponsored project for which $\$ 450$ million was sanctioned. But the Bradford Morse commission raised some questions on environmental aspects of the dam which were supportive of the assessments of the critics of the project in India. The activists' agitation is because of their environmental concerns and also because of the questions of resettlement and rehabilitation of the villagers and of land acquisition.

\section{References}

1 Barry Commoner, Making Peace with the Planet. Pantheon Books, 1990.

2 Jessica Tuchman Mathews (ed.), Preserving the Global Environment: the Challenge of Shared Leadership. Norton, 1991.

3 Choucri, Nazli. 'The Global Environment and Multinational Corporations', Technological Review, April 1991.

4 . Vandana Shiva, 'Conflicts in Global Ecology', The India Magazine, August 1992.

\title{
Environmental Awareness: The Hindu Perspective
}

\author{
R. Vijayalakshmi \\ International Institute of Tamil StudiesTaramani, Madras
}

THE OLDEST RELIGION of the people of India is Hinduism. It is a religion which was not propounded by a single individual, but was evolved out of the developments spanning several millennia. It has the distinction that it has assimilated the unique features of all the ages through which it evolved. From the time of its appearance it has grown by adapting itself to its environment. Several works have come forth as an expression of its doctrines from the very beginning. But there is no single gospel for Hinduism as, say, the Bible is for Christianity. The Vedas, the Brahmanas, the Upanishads, the Puranas, the Ithihasas, all reflect the thought of Hindu religion. In order to discuss the environmental awareness from the Hindu perspective it is necessary to find out what these various scriptures have to say about this. Even before that it is necessary to define the concept of environmental awareness.

It may be said that environmental awareness consists of the efforts made by people to live in harmony with their surroundings. The land on which they live, the fauna and flora in it, the climate and the weather, water, light, all come under the category of environment. Even if the balance of people and their surroundings were to be disturbed in the slightest manner, there is scope for disharmony in human life. The 
entire lifestyle of human beings has been changed completely by the technological revolution and population explosion in the world. In earlier times, people were satisfied with minimal comforts which they could derive from their narrow surroundings. But with the increase in population, the area of land occupied by people has also grown enormously. People also resort to technological innovations in order to satisfy their wants. With technological growth their desires also increase and multiply. In the course of time people have also started abusing the very surroundings which support their existence. Hence there is pollution.

Environmental awareness will help people to leave behind a world which is better than what it was during their lifetime. Would it be possible for men to satisfy their needs without exploiting the environment? The answer is 'No'. But even while exploiting the environment, people should see that its fertility does not dwindle and that it does not get depleted or degraded. It is only because of the enormous abuse of the environment in the quest for his economic necessities that the realisation about environmental conditions has come into existence on a global scale. In this context it appears worthwhile to examine how Hinduism has looked at the question of environmental awareness.

Hinduism at the beginning was a religion which had environmental awareness as one of its manifestations. Many Vedic hymns are songs which identify man as part of his environment. In the earlier stages nature was mainly personified; with the passage of time personification gave way to deification. Air, Sun, Fire, Rain, Storm everything which played a key role in satisfying the basic needs of people, is extolled in the hymns of the Vedas. They were deified, respected and worshipped either during various seasons or according to particular localities. This deification and personification of the various aspects of the environment naturally created a respect and care for the environment. The most important gods, viz. the chief triad of Vedic Gods,
Indra, Surya and Agni, are only the personification of the watery atmosphere, the source of heat and light, and fire. Likewise the dawn, the wind, the assemblage of moving power and some of the natural aspects which are personified as Ushas, Vaya and Maruts. Even earth is considered as the mother of all beings and is named as 'PrthvI' (the broad one).

People were curious about the mystery of creation and this is clear in the Rigveda verses of the Xth Mandala and a relevant part is given below:

In the beginning there was neither nought or aught; Then there was neither sky nor atmosphere above. then enshrouded all this teeming Universe? In the receptacle of what was it contained? Was it enveloped in the gulf profound of water? Then there was neither day, nor night, nor light, nor darkness. ...1

Their curiosity about nature and their dependence on nature made them offer oblations to the gods. Butter ghee, soma juice, etc. were offered into the sacrificial fire, in the belief that fire would carry these oblations to whichever god they were extolling. In the course of time animals also came to be offered to gods during sacrifices. The vajasaneya Samhita of the white Yajur veda enumerates different kinds of sacrificial offerings which are suitable for various sacrifices. ${ }^{2}$

This situation, however, underwent a change with the advent of non-vedic heterodox sects such as Buddhism, Jainism and Ajivikism. The concept of Ahimsa which was stressed by these religions paved the way for the cessation of offering animals in sacrifices and also helped in the protection of the environment. The thought that birds and animals are for the use of the man gave way to the concept of the sanctity of all forms of life.

The cow which gives milk, curd and ghee came to be considered as an animal which should not be killed. The killing of a cow became a sin which was punishable as a 
serious offence. Manusmiti enjoins that the killing of a cow should be avoided at any cost (XI. 60-65). This injunction is upheld to this day. Later-day inscriptions have gone to the extent of comparing other offences with that of killing a milch-cow on the banks of the river Ganga.

A part of the following chola inscription dated 1258 C.E. serves as a good example:

We drafted this Nilaimai Pramana (the perpetual compact after cutting a goat in the temple of Jayamkonda Nacchiyar (on Tuesday, equal unto Pancami, 23rd day in the month of Simha) after offering worship.

We all the members also got this tone inscription engraved in the temple of lord of Edavanturai.

One who acts against this stone inscription will incur the sin of stabbing a Cow, in between the Ganges and Kumari. ${ }^{3}$

The Hindu religion also stresses vigilance in the conservation of trees. Trees which bear fruit and help in producing rain and in cleansing the atmosphere, were protected with assiduous care. The Manusmrti declares that the cutting of trees for fuel should be avoided (XI: 65). The benefits bestowed by trees on man also led to a situation in which they were even deified. Besides, the flowers, fruits, bark and seeds of trees were also used in medicine and as protective talismans right from the time of Atharva Veda.

Even in very early times before people came to know about agriculture, trees provided them with most of their essential requirements. The trees like Pipal, Bar and Gooler provided cool shelter from the hot sun and naturally these trees were planted and nursed with great respect. In the epic Ramayana Ravana, when faced with calamity, speaks as follows:

... I have not cut down any fig tree in the month of Vaisakh, why then does this calamity befall me?
This serves as a good example to illustrate how Hindus respected trees which constituted a large part of our environment.

Sometimes trees are also considered by the Hindus as incarnations of God. In the Bhagavadgita Lord Krishna says that he is the Pipal tree among all the trees (... Asvatthah sarvavrkshanam ... 10:26). To create an awareness among the people the Varaha Purana states the following:

He never goes to hell who plants an Asvatha, or a Pichumarda, or a Banyan, or ten Jessimines, or two pomegranates, or a Panchamra or five Mangoes.

To encourage tree plantation the Hindu texts like Skandapurana recommend which trees could be planted and in which direction. For example, Skandapurana says that a Vilva tree should be planted at the centre, and four other Vilva trees on its four sides. In the four corners four Banyan trees and twenty-five Asoka trees in a circle and a myrobalan tree (Amla) on one side also should be grown.

The festivals like Durvastami, Asokastami and Madanotsava are some of the festivals during which people worshipped trees. On the whole the reverence for trees is deeply rooted among the Hindus.

The Hindu texts always created a greater awareness regarding the conservation of water which is one of the most important environmental resources. Because of its indispensable nature, it is considered to be of a divine nature and the following Rigveda verse (VII: 49:2) is a good example to illustrate this idea: '... The water from the heaven, the waters from the spring, the bright pure waters which tend to the sea, may those divine waters protect me here. ...' Water was never allowed to be stolen and the Manusmrti says that 'it was considered wrong when somebody steals the waters of wells and cisterns' (XI.164).

It also adds that, ' $\mathrm{He}$ who shall take away the waters of a tank, made in ancient times or shall cut off the supply of water 


\section{Viewpoints}

must be made to pay the first (or lowest) amercement' (IX.281). Hinduism also considered water as one of the first primordial elements (panca maha bhutas) and the vedic Rshis respected water as the beginning, the root, the centre and the termination of human beings.

Where, water, is your beginning, where your root, where your centre, where indeed is your termination' (Rigveda VII: 6:12). The flowing river as well as the stationary water reservoirs are regarded as sacred by the Hindu religion. Moving, flowing or falling water is considered to have great cleansing power. Rivers like Ganga are deified and it is believed that even a drop of water from the Ganga eradicates all the sins accumulated over several lifetimes and as the ladder to the heaven, as the river is believed to have descended from heaven (svarga-sopanasarani). Moreover, rivers are also considered as mother for they nurture the land and the people who reside in the land. To sum up, according to Hinduism every creation of this world is a part of God. All of us have importance in the flow of nature. When this importance is not realised and human beings try to imbalance nature, disaster arises. Hinduism insists that the rough-and-tumble world should be dealt with in a manner in which everything is maintained in a balanced state. This feeling is felt through the following Atharva vedic hymns:

What, O earth, I dig out of thee, quickly shall that grow again; may I not, $\mathrm{O}$ pure one, pierce thy vital spot, (and) not thy heart!

Thy summer, $\mathrm{O}$ earth, thy rainy season, thy autumn, winter, early spring, and spring; thy decreed yearly seasons, thy days and nights shall yield us milk! $\quad(X: 35: 36)$.

To have a balanced, peaceful life, let the human world create less disturbance to our surroundings. Substantial efforts in planting trees, conserving soil, protecting biological diversity, and finding new ways of producing natural energy could help to a greater extent in maintaining a balanced environmental harmony in our present world.

\section{Notes}

1. Rigveda X:129, M. Williams, Hinduism, Delhi, 1971, p.26.

2 Ibid. p.38

3 R. Nagsamy, Studies in Ancient Tamil Low and Society. Madras, The Institute of. Epigraphy, 1978, p.83.

\section{In Memoriam}

Father Bede Griffiths, OSB (Cam.) 1906 - 1993

With open mind and open heart, Father Bede brought new light

to East-West dialogue. His life's journey is a legacy to carry forward

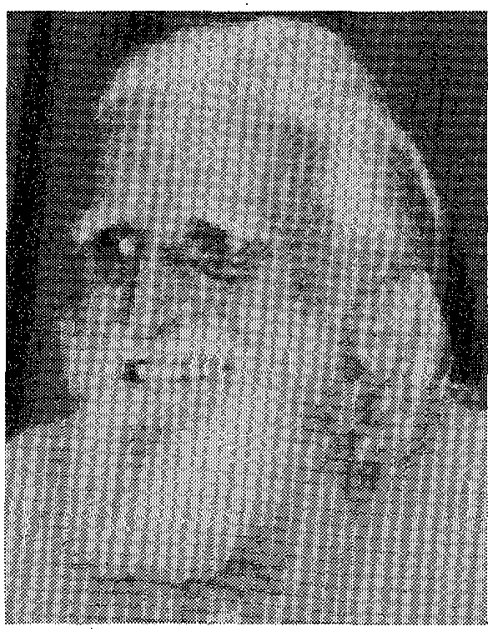

